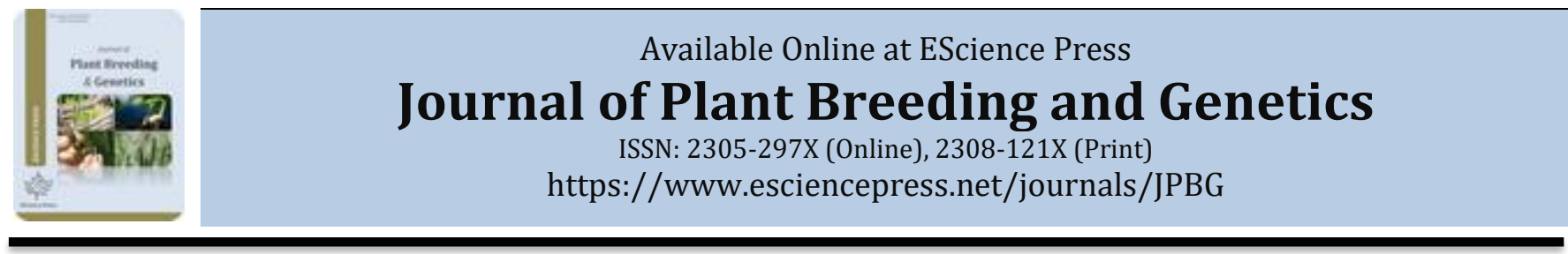

\title{
DEVELOPMENT AND RELEASE OF TWO MID-LATE MATURING MAIZE HYBRIDS FOR THE HIGHLAND AGRO-ECOLOGIES OF UGANDA
}

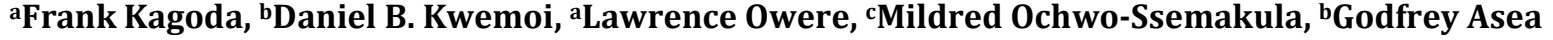 \\ a National Agricultural Research Organisation - Buginyanya ZARDI, P.O. Box 1356, Mbale, Uganda. \\ b National Agricultural Research Organisation - NaCRRI, Namulonge, P. O. Box 7084 Kampala, Uganda. \\ c Makerere University, College of Agricultural and Environmental Sciences, Kampala, Uganda.
}

Corresponding Author: Frank Kagoda Email: fkagoda@gmail.com Tel: +256772898988

\section{A B S T R A C T}

The maize yield in the highland areas of Uganda (1500 to 3000 masl), rarely exceeding $2 \mathrm{t} \mathrm{ha}^{-1}$. The use of unimproved maize genotypes, the prevalence of pests and diseases, and low levels of input use has tremendously contributed to the low grain yields. Accordingly, we obtained 100 maize inbred lines majorly from CIMMYT in the year 2013. The inbred lines were evaluated for adaptability and those selected were intercrossed to generate 80 single cross hybrids by January 2015. The 80 single cross hybrids were evaluated in preliminary yield trials in three sites namely, Kachwekano, Kalengyere and Buginyanya in 2015a season. The best combiners were crossed with the selected males to obtain 122 three-way cross hybrids. These were evaluated for adaptability in advanced yield trials in 2016a in Kachwekano, Kalengyere and Bukwo, from where the best five hybrids (BH33, BH31, BH27, BH104 and BH38) were selected for National Performance Trials (NPT) in 2016b and 2017a seasons in Bukwo, Buginyanya, Zombo, Fort portal and Kalengere. Two candidate varieties namely BH31 and BH33 exhibited good agronomic qualities such as earlier maturity, tolerance to MLN and other diseases. The selected hybrids yielded $8.2 \mathrm{t} \mathrm{ha}^{-1}$ and $7.2 \mathrm{t} \mathrm{ha} \mathrm{h}^{-1}$ for BH31 and BH33, respectively. The two varieties are appropriate for cultivation in major highland and transitional maize growing regions in Uganda and were subsequently released as NAROMAIZE 731 and NAROMAIZE 733, respectively. The newly released varieties are expected to reduce the highland maize cropping season from over six months to five months.

Keywords: GCA, SCA, Wheat genotypes, Drought stress, Diallel.

\section{INTRODUCTION}

Uganda's highland areas are covered by the montane agro-ecology system (MAAIF 1995), found at elevations of $1500-3000 \mathrm{~m}$ above sea level. The annual average rainfall in such areas is between 1500 and $2000 \mathrm{~mm}$, with an average minimum temperature of $15^{\circ} \mathrm{C}$ and maximum of $28^{\circ} \mathrm{C}$, and $80 \%$ relative humidity (Fews net, 2005). Districts covered by the montane system in Uganda include Kapchorwa, Sironko, Bududa, Bukwo, Bulambuli, Manafwa, Kween, Mbale, Kisoro, Kabale and Kasese. These districts are characterized by high human population intensities and intensive agriculture because of small landholdings averaging about 1.5 hectares. Stagnation or decline of maize grain yield has been registered in the last 30 years, with yields hardly exceeding $2 \mathrm{t} \mathrm{ha}^{-1}$ among the peasant communities in these agro-ecologies (DSOER, 2004). The extensive use of unimproved maize genotypes, the prevalence of pests and diseases, little improvement in agronomic and postharvest technologies and low usage of purchased inputs such as fertilizers and other agrochemicals has contributed to the low yields in maize. This is because no hybrid cultivars have been bred specifically for the highland areas of Uganda. In the highlands of southwestern Uganda, farmers rely on recycled and local varieties as well as growing low and mid-altitude cultivars for lack of a better alternative. Highland farmers in eastern Uganda mainly source seed for hybrid varieties from Kenya, incurring very high unit costs of production and delayed planting (Abalo, 2007). With breeding interventions, new maize varieties adapted to the high altitude areas of Uganda could lessen the problem of high seed cost and shortage. 


\section{MATERIALS AND METHODS}

\section{Breeding, evaluation and selection procedure}

Initial germplasm used was obtained from CIMMYT Ethiopia
(60 lines), CIMMYT Nairobi (30 lines) and KALRO Kitale (10 lines) though only the germplasm used to develop the candidate varieties have been presented here (Table 1).

Table 1. Selected inbred lines used to develop the 31 three-way cross hybrids evaluated at AYT.

\begin{tabular}{|c|c|c|c|}
\hline $\begin{array}{c}\text { Stock } \\
\text { ID }\end{array}$ & Line Code & PEDIGREE & Characteristics \\
\hline 7 & AMH704-14 & $\begin{array}{l}{[\mathrm{KIT} / \mathrm{SNSYN}[\mathrm{N} 3 / \mathrm{TUX}] \mathrm{c} 1 \mathrm{~F} 1-} \\
\# \#(\mathrm{GLS}=2.5)-34-2-1-1-1-\#-\#-\#-\#-\#- \\
\#\end{array}$ & $\begin{array}{l}\text { Medium height, semi-dent seed texture, small seed } \\
\text { size, medium maturity and electrophile leaf type. }\end{array}$ \\
\hline 10 & AMH704-22 & $\begin{array}{l}\text { [POOL9Ac7-SR(BC2)]FS59-4-1-2-1- } \\
\text { 1-2-1-2-\#-\#-\#-\#-\# }\end{array}$ & $\begin{array}{l}\text { Medium height, semi-dent seed texture, medium } \\
\text { seed size, early maturity and semi-erect leaf type. }\end{array}$ \\
\hline $14^{\checkmark}$ & AMH704-43 & $\begin{array}{l}\text { [POOL9Ac7-SR(BC2)]FS69-1SR-1-2- } \\
\text { 2-2-\#-1-\#-\#-\#-\#-\# }\end{array}$ & $\begin{array}{l}\text { Medium height, dent seed texture, large seed size, } \\
\text { early maturity and semi-erect leaf type, good male, }\end{array}$ \\
\hline 16 & AMH704-46 & $\begin{array}{l}\text { [ECU/SNSYN[SC/ETO]]c1F1- } \\
\# \#(G L S=1.5)-3-2-1-2-\#-3-\#-\#-\#-\#-\#\end{array}$ & $\begin{array}{l}\text { Quite late maturing with planophile leaves; Semi } \\
\text { dent, resistant to TLB, medium height, coloured silks }\end{array}$ \\
\hline 20 & AMH704-51 & $\begin{array}{l}{[\mathrm{KIT} / \mathrm{SNSYN}[\mathrm{N} 3 / \mathrm{TUX}]] \mathrm{c} 1 \mathrm{~F} 1-} \\
\# \#(\mathrm{GLS}=1)-1-2-1-2-1-\#-\#-\#-\#-\#\end{array}$ & GLS resistant \\
\hline 23 & AMH701-2 & $\begin{array}{l}\text { [POOL9Ac7-SR(BC2)]FS150-2-1-2- } \\
\text { 1-1-4-2-\#\#\#-\#-\#-\# }\end{array}$ & $\begin{array}{l}\text { Medium height, semi-dent seed texture, small seed } \\
\text { size, erectophile leaves, resistant to TLB. }\end{array}$ \\
\hline 28 & AMH701-9 & $\begin{array}{l}\text { [POOL9Ac7-SR(BC2)]FS232-4-1-3- } \\
\text { 1-2-2-1-\#\#-\#-\#-\# }\end{array}$ & $\begin{array}{l}\text { Medium height, semi-dent seed texture, medium } \\
\text { seed size, early maturity and planophile leaf type. }\end{array}$ \\
\hline 32 & AMH701-20 & $\begin{array}{l}\text { [ECU/SNSYN[SC/ETO]]c1F1- } \\
\# \#(\mathrm{GLS}=2.5)-36-2-1-1-\#-\#-\#-\#-\#\end{array}$ & $\begin{array}{l}\text { Semi-dent seed texture, small seed size, late } \\
\text { maturity and semi-erect leaf type. }\end{array}$ \\
\hline 39 & AMH703-11 & $\begin{array}{l}\text { [KIT/SNSYN[N3/TUX]]c1F1- } \\
\# \#(G L S=25)-17-1-1-2-1-\# \# \#-\#-\#-\#\end{array}$ & $\begin{array}{l}\text { Quite late maturing with erectophile leaves; Semi } \\
\text { dent, resistant to TLB }\end{array}$ \\
\hline 44 & AMH703-22 & $\begin{array}{l}\text { [POOL9Ac7-SR(BC2)]FS45-3-2-2-1- } \\
\text { 2-\#*4-\#-\#-\# }\end{array}$ & $\begin{array}{l}\text { Short, dent seed texture, large seed size, late } \\
\text { maturity and semi-erect leaf type. }\end{array}$ \\
\hline 51 & AMH703-34 & $\begin{array}{l}\text { [POOL9Ac7-SR(BC2)]FS211-1SR-1- } \\
\text { 1-1-\#-\#-\#-\# }\end{array}$ & $\begin{array}{l}\text { Tall, dent seed texture, small seed size, early } \\
\text { maturity and planophile leaf type. }\end{array}$ \\
\hline $52 \checkmark$ & AMH703-35 & $\begin{array}{l}\text { SRSYN95[ECU//SC/ETO]F1- } \\
\# \#(G L S=3.5)-20-2-1-1-\#-\#-\#-\#-\#\end{array}$ & $\begin{array}{l}\text { Tall, dent seed texture, large seed size, early } \\
\text { maturity and semi-erect leaf type. }\end{array}$ \\
\hline 54 & AMH703-37 & $\begin{array}{l}\text { [POOL9Ac7-SR(BC2)]FS67-1-2-3-1- } \\
\text { \#-\#-\#-\#-\# }\end{array}$ & $\begin{array}{l}\text { Medium height, dent seed texture, medium seed } \\
\text { size, late maturity and planophile leaf type. }\end{array}$ \\
\hline ML10 & & ZM523A-16-2-1-1-B*5-B-B-B-B & MLN tolerant, good male \\
\hline ML18 & & $\begin{array}{l}\text { [CML444/CML395//DTPWC8F31-1- } \\
\text { 1-2-2-BB]-4-2-2-2-1-BB-B-B-B-B-B }\end{array}$ & MLN tolerant \\
\hline ML19 & & $\begin{array}{l}\text { La Posta Seq C7-F64-2-4-1-1-B-B-B- } \\
\text { B-B-B-B }\end{array}$ & MLN tolerant \\
\hline ML21 $\checkmark$ & CKDHL120664 & & MLN tolerant, short plant height \\
\hline ML22 & CML494 & & MLN tolerant, good male \\
\hline ML26' & CKDHL120671 & & MLN tolerant, medium plant height \\
\hline ML30 & CKSBL10060 & & MLN tolerant, good male \\
\hline K-1 & KRHL-1 & & Late maturing, poor nicking \\
\hline W-7 & WANAK-C & & Very late maturing, poor nicking \\
\hline
\end{tabular}

${ }^{*}$ All the lines found resistant to common foliar diseases (TLB, MSV, GLS, rust, and PLS). $\checkmark$ Parents of BH31 and BH33. 
Out of the 100 lines obtained in the first season, 25 were selected based on adaptability and tolerance to diseases. A total of 10 inbred lines were intercrossed in a diallel nursery in 2015a, and the remaining 15 used as male parents due to their stress tolerance potential and production of plenty of viable pollen. A total of $90 \mathrm{~F}_{1}$ single cross hybrids were generated and 80 hybrids with adequate seed were evaluated in a preliminary yield trial (PYT) in three sites, namely Kachwekano (Kachwekano),
Kalengyere (Kalengyere) and Buginyanya (Buginyanya) in 2015a season (Kayaga et al. 2017a; Kayaga et al. 2017b).

Hybrids with high specific combining ability (SCA) following the PYT were top-crossed with nine selected males. Consequently, a total of 122 three-way cross hybrids were obtained and evaluated for adaptability in advanced yield trials (AYTs) during 2016a season in Kachwekano, Kalengyere and Bukwo (Figure 1).

\section{5 best combiners selected}

Test cross with $15 \mathrm{MLN}$

122 three-way cross hybrids obtained

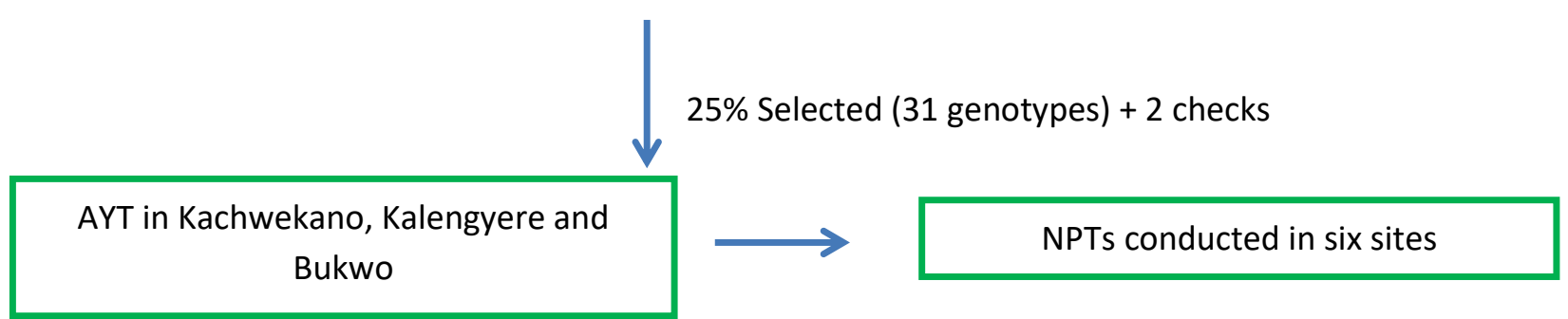

Figure 1. Breeding and selection procedure used to develop the three-way cross hybrids.

Of the 122 hybrids, five (BH33, BH31, BH27, BH104 and BH38) were selected for National Performance Trial (NPT) in 2016b and 2017a seasons.The NPTs were conducted in six sites namely, Bukwo district -Bukwo, Bulambuli district - Buginyanya, Bulambuli District Bulegeni, Zombo District - Zeu, Fort Portal District Rwebitaba and Rubanda District - Kalengyere. Fort Portal and Zombo are considered transitional zones (1300 1500 masl). Common highland maize hybrids and midlate hybrids were used as commercial checks.

\section{Data collection and analysis}

Data on disease severity such as turcicum leaf blight (TLB), maize streak virus (MSV), gray leaf spot (GLS), maize lethal necrosis (MLN) and common rust (rust) were based on percent leaf area infected and were recorded at silk dry stage using visual scales of 1-5, where 1 = leaves free from infection, $2=$ a few restricted lesions on the lower leaves, $3=$ several small and large lesions on many leaves, $4=$ numerous small and large lesions on many leaves, 5 = many enlarged and coalesced lesions on many leaves above the cob (Magorokosho et al. 2007). Other data sets collected included: Days to anthesis (DTA), Anthesis-silking interval (ASI), plant height, ear height, ears per plant (EPP), grain yield, number of kernel rows per cob, ear rot, root and stem lodging. A participatory variety selection (PVS) exercise of preferred hybrids was conducted by a total of 100 participants comprising 85 farmers, ten research scientists/technicians, three seed traders, and two extension agents. Their role in the PVS was to rate hybrids, based on their tests and preferences, on a scale of 1-5, where 1 = Excellent hybrid, 2 = Very good hybrid, 3 = Good, 4 = Poor hybrid, 5 = Very poor hybrid Additionally, we screened for MLN in the various hotspots and under artificial inoculation at CIMMYT Naivasha in 2016a season to consistent disease rating. In Naivasha, 
the MLN scale used was 1-9, where $1=$ No symptoms observed, $5=$ moderate symptoms, $9=$ Extensive damage.The hybrids were later ranked based on key attributes such as ASI, PVS, grain yield and TLB resistance. Data collected were used to calculate general combining ability (GCA) of the inbred lines and SCA of the hybrids. Analysis of variance (ANOVA) was conducted using SAS statistical software. Heritability was estimated using Genstat software. Since the genotype by environmental interaction (GEI) was significant, genotype and genotype by environmental (GGE) biplot analysis was performed using PAST Software to generate graphs that showed the mega environments and enabled comparison of sites to the ideal site and genotypes to the ideal genotype as reported by Yan and Tinker (2006). Precisely, the use of GGE biplot analyses provides a clear basis for determining the stability and performance of these hybrids.

\section{RESULTS}

\section{Selection of single cross hybrids as female parents}

Combined analysis of variance for PYT showed significant variation among test environments $(\mathrm{P}<0.01)$ for all the traits except ear length, grain yield and number of kernel rows (Table 2).

Table 2. Mean squares following ANOVA for yield and yield related traits of $36 \mathrm{~F} 1$ hybrids evaluated across three highland locations of Uganda.

\begin{tabular}{lclllllll}
\hline $\begin{array}{l}\text { Source of } \\
\text { variation }\end{array}$ & $\mathrm{df}$ & $\begin{array}{l}\text { Anthesis- } \\
\text { silking } \\
\text { interval }\end{array}$ & $\begin{array}{l}\text { Ears per } \\
\text { plant }\end{array}$ & $\begin{array}{l}\text { Ear } \\
\text { diameter }\end{array}$ & $\begin{array}{l}\text { Ear } \\
\text { length }\end{array}$ & $\begin{array}{l}\text { Husk } \\
\text { cover (\%) }\end{array}$ & $\begin{array}{l}\text { Nr of } \\
\text { kernel } \\
\text { rows }\end{array}$ & $\begin{array}{l}\text { Grain } \\
\text { yield }\end{array}$ \\
\hline ENV & 2 & $10267^{* * *}$ & $1.54^{* *}$ & $322.3^{* *}$ & 34.54 & $7291^{* *}$ & 5.36 & 368 \\
REP(ENV) & 3 & 0.074 & 0.02 & $7.42^{* * *}$ & 4.12 & 219 & $4.69^{*}$ & $46^{* * *}$ \\
ENTRY & 35 & $378^{* * *}$ & 0.29 & 3.4 & $11.6^{* *}$ & $1089^{*}$ & 3.98 & 4.27 \\
GCA & 8 & $1555^{*}$ & 0.31 & 1.84 & $19.2^{*}$ & 991 & 9.78 & 5.03 \\
SCA & 27 & $29.5^{* * *}$ & 0.29 & 3.86 & $9.31^{*}$ & $1118^{*}$ & 2.26 & 4.05 \\
ENV*ENTRY & 70 & $120.8^{* * *}$ & $0.24^{* * *}$ & $3.09^{* * *}$ & $5.03^{*}$ & $633^{* * *}$ & $3.55^{* * *}$ & $4.36^{* * *}$ \\
ENV*GCA & 16 & $501.6^{* * *}$ & $0.17^{* *}$ & $3.31^{* *}$ & $5.97^{*}$ & $564^{*}$ & $4.3^{* *}$ & $5.57^{* *}$ \\
ENV*SCA & 54 & $7.98^{* * *}$ & $0.26^{* * *}$ & $3.03^{* * *}$ & 4.75 & $654^{* * *}$ & $3.32^{* *}$ & $4.01^{* *}$ \\
ERROR & 105 & 2.71 & 0.07 & 1.20 & 3.41 & 316.48 & 1.70 & 5.22 \\
V.GCA & & 50.2 & 0.01 & -0.07 & 0.63 & 20.31 & 0.26 & -0.03 \\
V.SCA & & 7.17 & 0.01 & 0.28 & 1.52 & 155 & -0.35 & 0.01 \\
V.GCA x ENV & & 71.3 & 0.01 & 0.30 & 0.37 & 35.4 & 0.37 & 0.05 \\
V.SCA x ENV & & 5.3 & 0.19 & 1.83 & 1.34 & 337.5 & 1.62 & -1.21 \\
BS.CGD & & 0.81 & 0.23 & 0.23 & 0.71 & 0.52 & 0.36 & 0.02 \\
NS.CGD & & 0.75 & 0.13 & 0.00 & 0.32 & 0.11 & 0.36 & 0.00 \\
BR & & 0.93 & 0.57 & 0.00 & 0.45 & 0.21 & 1.00 & 0.00 \\
\hline
\end{tabular}

Significance level, ${ }^{*}=\mathrm{P} \leq 0.05,{ }^{* *}=\mathrm{P} \leq 0.01,{ }^{* * *}=\mathrm{P} \leq 0.001, \mathrm{GCA}=$ General combining ability, $\mathrm{SCA}=$ Specific combining ability. ENV x GCA= Interaction of environment by genotype (GCA), ENV x SCA=Interaction of the environment by crosses (SCA), V.GCA= Variance due to GCA, V.SCA=Variance due to SCA, V.GCA $\times$ ENV=Variance due to interaction between genotype (GCA) and Environment. V.SCA x SCA=Variance due to interaction between crosses (SCA) and Environment, BS.CGD \& NS.CGD=Broad sense and Narrow sense Coefficients of genetic determination, BR= Bakers ratio.

The inbred lines showed significant GCA effects for days to silking, anthesis-silking interval and ear length $(\mathrm{P}<$ 0.05). The SCA effects of the hybrids were also significant $(\mathrm{P}<0.05)$ for anthesis-silking interval and ear length. Environment $\mathrm{x}$ hybrids and environment $\mathrm{x}$ GCA interactions effects were highly significantly different $(\mathrm{P}<0.001)$ for grain yield and all the yieldrelated traits. The interaction effects of environment $\mathrm{x}$
SCA were highly significant $(\mathrm{P}<0.01)$ for grain yield and all the yield-related traits except days to silking and ear length. Inheritance of ear length and anthesis-silking interval was controlled by both additive and nonadditive gene action while the inheritance of days to anthesis, days to silking was mainly controlled by additive gene action. The inheritance of grain yield and other yield related traits was greatly influenced by 
environment and genotype $\mathrm{x}$ environment interaction. Some of the best combiners which were eventually top crossed to get the 122 three-way cross hybrids are presented in Table 1 and Kayaga et al. (2017).

\section{Performance of the three-way highland maize hybridsat AYT}

Advanced yield trials (AYTs) were conducted during the 2016a season in Kachwekano, Kalengyere and Bukwo. The best 31 hybrids (25\%) were selected (Table 3).

Table 3 - Results of the three-way cross hybrids at AYT across three sites in 2015a season

\begin{tabular}{|c|c|c|c|c|c|c|c|c|c|c|c|c|}
\hline $\mathrm{S} / \mathrm{N}$ & Hybrid & $\begin{array}{l}\text { Plant ht } \\
(\mathrm{cm})\end{array}$ & $\begin{array}{c}\text { Ear ht } \\
(\mathrm{cm})\end{array}$ & DTA & $\begin{array}{c}\text { ASI } \\
\text { (days) }\end{array}$ & $\begin{array}{c}\text { TLB } \\
(1-5) \\
\end{array}$ & $\begin{array}{l}\text { MLN } \\
(1-9)\end{array}$ & EPP & $\begin{array}{l}\text { No. of } \\
\text { rows }\end{array}$ & $\begin{array}{c}\text { Grain yield } \\
(\mathrm{t} \text { ha- } 1)\end{array}$ & $\begin{array}{l}\text { PVS } \\
\text { score }\end{array}$ & Rank \\
\hline 1 & BH33 & 219 & 110 & 108 & 1.3 & 1.9 & 4.5 & 1.6 & 14.8 & 7.2 & 2.8 & 1 \\
\hline 2 & BH31 & 198 & 91 & 106 & 0.5 & 1.7 & 4.0 & 2 & 15.1 & 8.2 & 3.3 & 2 \\
\hline 3 & BH38 & 187 & 93 & 109 & 1 & 1.8 & 4.0 & 1.4 & 11.5 & 5.0 & 3.4 & 3 \\
\hline 4 & BH104 & 207 & 108 & 108 & 1.3 & 1.9 & 4.0 & 1.4 & 13.1 & 6.3 & 3.3 & 4 \\
\hline 5 & BH27 & 212 & 104 & 109 & 2.8 & 1.8 & 4.3 & 1.6 & 13.3 & 7.7 & 3.3 & 5 \\
\hline 6 & BH114 & 203 & 109 & 109 & 2.8 & 1.5 & 4.0 & 1.2 & 13.5 & 5.2 & 2.8 & 6 \\
\hline 7 & BH106 & 208 & 108 & 108 & 2.8 & 1.9 & 5.0 & 1.2 & 14.4 & 4.2 & 3.7 & 7 \\
\hline 8 & BH90 & 199 & 91 & 105 & 4.3 & 1.9 & 4.0 & 1.9 & 12 & 10.8 & 3.3 & 8 \\
\hline 9 & BH44 & 181 & 88 & 110 & 3.5 & 1.5 & 4.0 & 1.2 & 14.2 & 4.8 & 3.4 & 9 \\
\hline 10 & BH94 & 216 & 101 & 103 & 2.5 & 1.6 & 4.3 & 1.3 & 13.7 & 4.4 & 3.3 & 10 \\
\hline 11 & BH95 & 185 & 83 & 98 & 3.8 & 2.1 & 4.0 & 1.3 & 12.6 & 4.8 & 3.7 & 11 \\
\hline 12 & BH89 & 211 & 112 & 100 & 2.8 & 2.1 & 4.5 & 1.4 & 13.9 & 5.7 & 3.9 & 12 \\
\hline 13 & BH15 & 220 & 107 & 101 & 4.8 & 1.6 & 5.0 & 1.3 & 12.9 & 5.3 & 3.3 & 13 \\
\hline 14 & BH48 & 185 & 88 & 99 & 3.8 & 2 & 5.0 & 1.2 & 13.3 & 3.4 & 3.3 & 14 \\
\hline 15 & BH108 & 202 & 109 & 110 & 2.5 & 2 & 5.0 & 1.1 & 14 & 4.4 & 3.1 & 15 \\
\hline 16 & BH16 & 209 & 94 & 109 & 0.5 & 3 & 4.0 & 1.4 & 13.2 & 7 & 3.8 & 16 \\
\hline 17 & BH20 & 186 & 82 & 108 & 1.5 & 3.5 & 5.0 & 1.8 & 13.2 & 5.8 & 3.9 & 17 \\
\hline 18 & BH28 & 215 & 111 & 113 & 1.5 & 3.8 & 4.0 & 1.6 & 13.4 & 5.6 & 3.6 & 18 \\
\hline 19 & BH32 & 197 & 97 & 107 & 2 & 2.5 & 4.0 & 1.5 & 12.8 & 6.4 & 3.1 & 19 \\
\hline 20 & BH34 & 227 & 113 & 109 & -1 & 3.5 & 4.5 & 1.6 & 13.2 & 6 & 3.4 & 20 \\
\hline 21 & BH43 & 212 & 101 & 110 & 1.5 & 2.5 & 4.0 & 1.2 & 13.3 & 4.7 & 3.8 & 21 \\
\hline 22 & BH56 & 208 & 105 & 111 & 1.5 & 3.3 & 5.0 & 1.6 & 13.6 & 6.5 & 3.5 & 22 \\
\hline 23 & BH59 & 196 & 103 & 111 & 0.3 & 3 & 4.0 & 1.7 & 14 & 5.8 & 3.8 & 23 \\
\hline 24 & BH62 & 202 & 96 & 111 & 1.8 & 2.8 & 4.3 & 1.4 & 13.7 & 7.4 & 3.3 & 24 \\
\hline 25 & BH81 & 199 & 93 & 105 & 2.3 & 2.3 & 4.3 & 1.5 & 13.1 & 6.3 & 3.4 & 25 \\
\hline 26 & BH97 & 194 & 89 & 109 & 2.8 & 1.9 & 4.5 & 1.5 & 12.8 & 6.8 & 3.7 & 26 \\
\hline 27 & BH103 & 195 & 95 & 101 & 1.8 & 2.9 & 4.0 & 1.6 & 12.9 & 3.9 & 3.5 & 27 \\
\hline 28 & BH110 & 212 & 112 & 110 & 2 & 2.4 & 4.5 & 1.3 & 12.9 & 3.6 & 3.3 & 28 \\
\hline 29 & BH113 & 196 & 94 & 108 & 1.8 & 3.1 & 4.5 & 1.5 & 12.7 & 5.8 & 3.8 & 29 \\
\hline 30 & BH76 & 180 & 81 & 99 & 3 & 1.4 & 5.0 & 1.4 & 13.2 & 5.2 & 3.4 & 30 \\
\hline 31 & BH24 & 197 & 94 & 111 & 2.5 & 1.8 & 5.0 & 1.2 & 14.2 & 4.7 & 3.4 & 31 \\
\hline 32 & H614D & 220 & 125 & 112 & 4.3 & 2 & 5.0 & 1.4 & 13.4 & 4.6 & 3.5 & 56 \\
\hline 33 & Mahinda & 210 & 99 & 112 & 1.8 & 2.9 & 5.0 & 1.3 & 13.7 & 2.7 & 3.5 & 108 \\
\hline \multicolumn{2}{|c|}{$\operatorname{LSD}_{(0.05)}$} & 79 & 56 & 8.8 & 6.6 & 1.6 & & 0.9 & 2.9 & 0.8 & 1.5 & \\
\hline \multirow{2}{*}{\multicolumn{2}{|c|}{$\begin{array}{l}\text { Trial mean } \\
\text { Check mean }\end{array}$}} & 197.2 & 95 & 105 & 3.1 & 2.1 & & 1.3 & 13.5 & 5.6 & 3.5 & \\
\hline & & 214.6 & 112 & 112 & 3 & 2.4 & & 1.3 & 13.5 & 3.7 & 3.5 & \\
\hline
\end{tabular}

Out of 122 hybrids evaluated at AYT, 25\% have been presented which gives 31 best hybrids. No significant levels of rust and MSV were recorded in the various experiments at AYT therefore not presented in the Table.

The selection was based on results from the data collected including a farmer participatory selection (PVS) exercise. Farmers' choice of a particular genotype was mainly based on earliness, pests and disease resistance, drought tolerance, grain yield and standability. Only five hybrids (BH33, BH31, BH27, BH104 and BH38) were selected for National Performance Trial (NPT) out of a total of 122 hybrids evaluated at AYT. 
Reason for selection depended on many factors, e.g., the average maturity period for these hybrids was about 216 days compared to 224 days for the best and local checks. Hybrids BH33 and BH31 also had a significantly higher number of kernel rows per cob (14.8 and 15.1 rows, respectively) compared to 13.4 rows in the best check and 13.7 rows in the local check. It is because of these many kernel rows and the number of kernels per cob that these hybrids were higher yielding compared to the checks.

\section{Performance of the candidate highland maize}

\section{varieties at NPT}

At NPT, two candidate varieties, BH31 and BH33, exhibited tolerance to the maize lethal necrosis, resistance to turcicum leaf blight, gray leaf spot and common rust (Table 4). The grain yield of BH31 was also significantly higher than that of the best check H614D. Both hybrids BH31 and BH33 were less susceptible to root and stem lodging compared to the check varieties. Specifically, taller varieties PAN691, H614 and H624 highly root lodged (33 $35 \%$ ) compared to hybrids BH31 and BH33 with only 7 to $17 \%$ root lodging (Table 4 ).The hybrids also flowered two weeks earlier than the best check. Therefore, these hybrids will give ample time to the farmer to prepare for the next crop and therefore be in time for the new rain season.

\section{Genotype and Genotype by Environment Biplot}

\section{(GGE) analysis}

The Genotype and Genotype by Environment (GGE) scatter plot confirmed the presence of genotype $x$ environmental interaction (GEI) effects as it showed the presence of three mega- environments, namely, Buginyanya highlands, Kalengyere highlands and the transitional areas of Bukwo, Bulegeni and Zeu (Figure 2). There were significant yield differences among test hybrids (Table 5).

Hybrid BH33 showed potential to perform well across all locations compared to the commercial checks H614D and H624 which only performed well in the eastern parts of the country. Hybrids BH27, BH31 and BH38 are more adapted in eastern and northwestern parts of the country. Under the transitional environment in Rwebitaba, hybrid BH27 was higher yielding; BH33 had better husk cover and the lowest ear rot attack. Also, worth noting is that BH31 and BH33 had much higher grain yield than the commercial checks Bazooka and $\mathrm{H} 624$ under transitional altitude.

Table 4. Performance of the hybrids across five highland locations at NPT.

\begin{tabular}{|c|c|c|c|c|c|c|c|c|c|c|c|c|c|c|}
\hline Name & $\begin{array}{c}\text { Across } \\
\text { rank }\end{array}$ & $\begin{array}{c}\text { Grain yield } \\
\left(\mathrm{t} \mathrm{ha}^{-1}\right)\end{array}$ & DTA & ASI & $\begin{array}{c}\text { Plant } \\
\text { height } \\
\text { (cm) }\end{array}$ & $\begin{array}{c}\text { Ear } \\
\text { height } \\
(\mathrm{cm})\end{array}$ & $\begin{array}{c}\text { Root } \\
\text { lodging } \\
(\%)\end{array}$ & $\begin{array}{l}\text { Stem } \\
\text { lodging } \\
(\%)\end{array}$ & $\begin{array}{c}\text { Husk } \\
\text { cover } \\
(\%)\end{array}$ & $\begin{array}{c}\text { GLS } \\
(1-5)\end{array}$ & $\begin{array}{c}\text { TLB } \\
(1-5)\end{array}$ & $\begin{array}{l}\text { MLN } \\
(1-5)\end{array}$ & $\begin{array}{c}\text { Grain Text } \\
(1-5)\end{array}$ & $\begin{array}{c}\text { Ear } \\
\text { Aspect } \\
(1-5)\end{array}$ \\
\hline BH38 & 3 & 5.4 & . & 1.2 & . & . & 3.5 & 2.8 & 22.9 & 1.5 & 2.2 & 1.5 & 2.1 & 3.5 \\
\hline BH31 & 3 & 5.5 & 72 & 0.7 & 207 & 91 & 7.0 & 5.3 & 19.9 & 1.8 & 1.8 & 1.0 & 1.8 & 3.5 \\
\hline BH27 & 2 & 5.1 & 73 & 1.6 & 204 & 90 & 12.1 & 7.5 & 11.2 & 1.6 & & 1.0 & 2.3 & 3.0 \\
\hline BH33 & 1 & 4.7 & 77 & 2.0 & 214 & 94 & 17.0 & 5.9 & 14.0 & 2.3 & 1.7 & 1.0 & 2.3 & 2.3 \\
\hline KH600-20A & 4 & 4.1 & 89 & 4.3 & 265 & 142 & 0.8 & 2.4 & 29.0 & . & . & 1.8 & 2.0 & 3.3 \\
\hline BH104 & 4 & 4.6 & & 0.7 & 216 & 104 & 4.7 & 3.7 & 33.4 & 2.0 & 2.1 & 1.0 & 2.9 & \\
\hline PAN691 & 1 & 4.3 & 80 & 2.9 & 228 & 121 & 34.0 & 26.6 & 10.4 & 1.3 & 1.1 & 1.0 & 2.0 & 3.0 \\
\hline H614 & 4 & 4.4 & 82 & 0.6 & 229 & 127 & 35.0 & 27.1 & 15.6 & 1.6 & 1.8 & 1.0 & 2.1 & 2.3 \\
\hline H624 & . & 5.1 & 80 & 2.4 & 249 & 133 & 33.0 & 11.7 & 10.0 & 1.5 & 2.2 & 2.3 & 1.3 & . \\
\hline Trial Mean & 3 & 5.5 & 78 & 2.4 & 232 & 120 & 15.1 & 10.2 & 16.5 & 1.7 & 1.8 & 1.3 & 2.1 & 2.7 \\
\hline $\mathrm{LSD}_{0.05}$ & 1 & 1.3 & 2.5 & 1.9 & 12.9 & 11.6 & 18.5 & 11.8 & 7.8 & 0.4 & 0.2 & 1.0 & 0.4 & 0.6 \\
\hline
\end{tabular}

DTA = Days to Anthesis; ASI = Anthesis - silking interval; TLB = Turcicum leaf blight; MLN = Maize lethal necrosis; TLB, GLS and MLN (1-5), $1=$ No symptoms observed, $5=$ Extensive damage. Grain texture (1-5), $1=$ flint, $2=$ flint like, $3=$ intermediate, $4=$ dent like, $5=$ Dent. Ear aspect $(1-5)$, where $1=$ clean, uniform, large, and well filled ears and $5=$ ears with undesirable features. 
Table 5. Performance per site of selected genotypes/traits at NPT.

\begin{tabular}{|c|c|c|c|c|c|c|c|c|c|c|c|c|}
\hline $\begin{array}{c}\text { Site/ } \\
\text { Variety }\end{array}$ & $\begin{array}{c}\text { Grain yield } \\
\left(\mathrm{t} \mathrm{ha}^{-1}\right)\end{array}$ & $\begin{array}{l}\text { Anthesis } \\
\text { date }\end{array}$ & ASI & $\begin{array}{c}\text { Husk } \\
\text { cover (\%) }\end{array}$ & EPP & $\begin{array}{c}\text { GLS } \\
(1-5)\end{array}$ & $\begin{array}{l}\text { P. sorg } \\
(1-5)\end{array}$ & $\begin{array}{c}\text { TLB } \\
(1-5)\end{array}$ & $\begin{array}{c}\text { Ear rot } \\
(\%)\end{array}$ & $\begin{array}{l}\text { MSV } \\
(1-5)\end{array}$ & $\begin{array}{c}\text { Ear Aspect } \\
(1-5)\end{array}$ & $\begin{array}{c}\text { Plant Aspect } \\
(1-5)\end{array}$ \\
\hline \multicolumn{13}{|l|}{ Bukwo } \\
\hline BH31 & 8.4 & 82.5 & 1.0 & 2.5 & 1.2 & 1.5 & 1.0 & 1.8 & 4.5 & 1.2 & 2.8 & 3.0 \\
\hline ВH33 & 5.2 & 84.0 & 1.0 & 1.9 & 0.9 & 1.0 & 1.0 & 1.7 & 3.9 & 1.6 & 3.0 & 2.5 \\
\hline H624 & 4.4 & 90.0 & 2.0 & 2.0 & 1.5 & 1.0 & 1.0 & 2.2 & 3.7 & 1.5 & 3.3 & 3.3 \\
\hline H614 & 4.1 & 88.9 & 2.4 & 2.8 & 2.3 & 1.5 & 1.0 & 1.8 & 5.7 & 1.5 & 2.7 & 2.7 \\
\hline \multicolumn{13}{|l|}{ Kalengyere } \\
\hline BH31 & 4.3 & 72.0 & 1.2 & 3.9 & 1.3 & 1.3 & 1.5 & 1.0 & 4.2 & 1.0 & 3.5 & 2.8 \\
\hline BH33 & 3.6 & 77.3 & 2.2 & 2.3 & 1.6 & 1.0 & 1.8 & 1.3 & 5.6 & 1.1 & 2.3 & 2.6 \\
\hline H624 & 4.5 & 90.8 & 2.3 & 1.9 & 1.6 & 1.2 & 1.0 & 0.9 & 3.7 & 1.6 & 2.8 & 2.1 \\
\hline H614 & 5.3 & 90.3 & 1.2 & 3.2 & 1.8 & 1.0 & 1.0 & 1.5 & 7.8 & 1.2 & 2.3 & 3.1 \\
\hline \multicolumn{13}{|l|}{ Zeu } \\
\hline BH31 & 5.4 & 72.3 & 2.5 & 2.5 & 0.9 & 2.5 & 1.2 & 2.2 & 0.1 & 0.6 & 3.3 & 3.5 \\
\hline ВH33 & 5.9 & 79.5 & 3.8 & 2.0 & 1.0 & 2.0 & 1.2 & 2.2 & 3.1 & 0.7 & 2.5 & 3.4 \\
\hline H624 & 4.4 & 90.5 & 2.3 & 2.0 & 1.5 & 2.0 & 1.2 & 2.3 & 0.1 & 0.8 & 3.5 & 2.1 \\
\hline H614 & 4.7 & 90.2 & 1.2 & 2.9 & 1.4 & 2.1 & 1.2 & 1.9 & 0.2 & 1.6 & 3.3 & 3.4 \\
\hline \multicolumn{13}{|l|}{ Bulegeni } \\
\hline BH31 & 5.7 & 50.7 & 1.2 & 1.8 & 1.4 & 1.0 & 1.0 & 1.5 & 5.5 & 2.2 & 2.7 & 2.3 \\
\hline ВН33 & 4.2 & 58.0 & 4.9 & 1.5 & 1.1 & 2.5 & 1.5 & 3.0 & 39.0 & 3.0 & 2.9 & 4.0 \\
\hline H624 & 4.3 & 57.5 & 1.8 & 2.8 & 1.4 & 1.0 & 1.0 & 1.0 & 17.0 & 2.3 & 3.0 & 2.0 \\
\hline H614 & 4.8 & 57.3 & 0.0 & 2.5 & 1.8 & 1.0 & 1.0 & 1.5 & 50.0 & 1.7 & 3.0 & 3.3 \\
\hline \multicolumn{13}{|l|}{ Buginyanya } \\
\hline BH31 & 4.1 & 82.4 & 0.2 & 2.4 & 1.0 & 1.3 & 1.2 & 2.1 & 8.1 & 1.3 & 3.1 & 3.2 \\
\hline ВН38 & 4.3 & 83.3 & 0.3 & 1.5 & 1.5 & 1.0 & 1.2 & 1.7 & 5.4 & 1.0 & 3.7 & 2.7 \\
\hline ВН33 & 3.9 & 87.5 & -0.9 & 1.9 & 1.2 & 1.0 & 1.2 & 1.9 & 8.7 & 1.6 & 2.8 & 2.8 \\
\hline H624 & 5.1 & 91.6 & 3.0 & 1.9 & 1.5 & 1.5 & 1.2 & 2.1 & 9.2 & 1.5 & 2.4 & 2.0 \\
\hline \multicolumn{13}{|l|}{ Rwebitaba } \\
\hline BH27 & 6.2 & & & 1.8 & 1.1 & 1.0 & 1.2 & 2.7 & 0.7 & 1.0 & 2.3 & 2.5 \\
\hline ВН38 & 5.6 & & & 1.5 & 0.9 & 1.0 & 1.2 & 2.8 & 1.0 & 1.0 & 2.7 & 3.0 \\
\hline ВН31 & 5.4 & & & 1.7 & 1.0 & 1.0 & 1.0 & 2.2 & 3.0 & 1.3 & 2.2 & 2.8 \\
\hline H628 & 4.9 & & & 1.7 & 0.8 & 1.2 & 1.0 & 2.5 & 4.7 & 1.5 & 2.5 & 3.2 \\
\hline SC719 & 4.5 & & & 1.0 & 0.9 & 1.0 & 1.2 & 2.3 & 2.0 & 1.2 & 1.3 & 2.5 \\
\hline ВН33 & 4.2 & & & 1.5 & 1.0 & 1.0 & 1.0 & 2.8 & 1.0 & 1.0 & 2.5 & 2.8 \\
\hline Bazooka & 3.8 & & & 1.5 & 0.4 & 1.2 & 1.0 & 2.5 & 36.3 & 1.5 & 3.0 & 2.7 \\
\hline H624 & 3.7 & & & 1.0 & 0.9 & 1.0 & 1.0 & 3.2 & 1.7 & 1.2 & 2.0 & 2.7 \\
\hline Mean & 4.8 & 78.8 & 1.7 & 2.1 & 1.2 & 1.3 & 1.1 & 2.0 & 8.4 & 1.4 & 2.8 & 2.8 \\
\hline
\end{tabular}




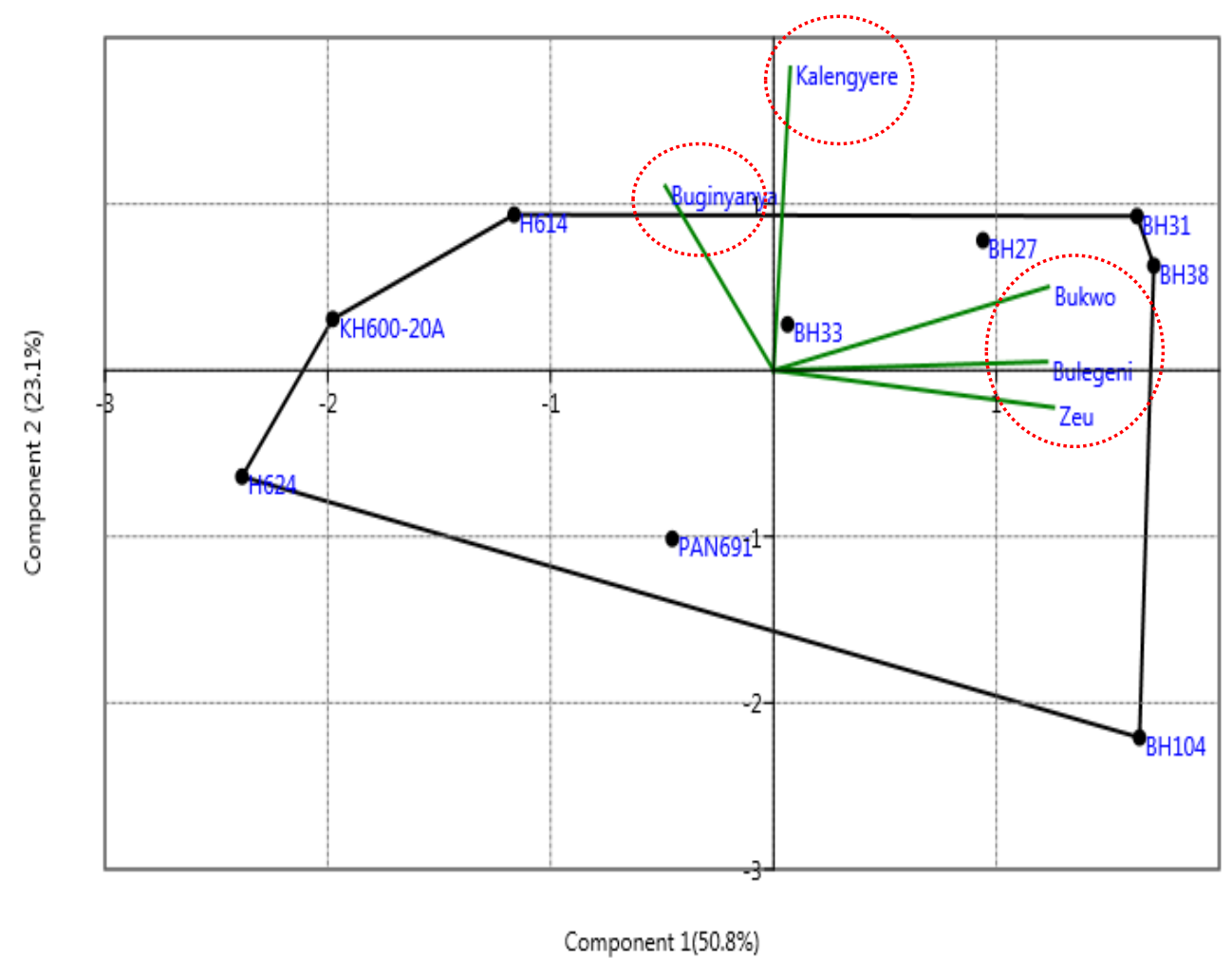

Figure 2. Mega-environments and winning vertex hybrids of grain yield for maize hybrids across five highland environments in Uganda during NPT.

\section{DISCUSSION}

Right from the PYT stage in this study, the role of environmental factors in the phenotypic expression of quantitative traits like yield could not be underestimated. Expectedly, significant environment effects were observed for most of the yield-related traits. Similarly, the mean squares of environment $x$ hybrid interaction effects for grain yield and all yield related traits were significant, showing that the relative difference observed in these hybrids' performance was not consistent across environments because of the influence of their specific interaction with each environment. At AYT stage, farmers were closely involved in the variety selection process. One major observation made during the trial is that all the varieties grown in these highland areas are very late maturing to the extent that they transit two rain seasons. However, the need for mixed crop enterprises, as pointed out by most of the farmers interviewed calls for mid-late maturing varieties in preference to very late maturing varieties. For example,Mr. Allan Musani a farmer group (32 members) leader from Ndishania village, Katreson parish, Bukwo District said, '...we rather have a maize variety which yields moderately but matures early, thereby giving room for another crop to be planted, than having a very late maturing crop which will render land unavailable for another crop for two seasons.'

Therefore, the five selected hybrids (BH33, BH31, BH27, BH104 and BH38) following the NPT were considered mainly because they took (on average) 216 days to mature, compared to 224 days for the best and local checks. Hybrids BH33 and BH31 were characterized by many kernel rows and a higher number of kernels per cob, making them more high yielding compared to the checks. Oteguia and Bonhommeb (1998) reported a positive correlation between grain yield and kernel number. According to Gautam et al., (1999), selection of number of kernels per row is highly effective for improvement of grain yield as opposed to the number of rows per cob.

At NPT, candidate varieties BH31 and BH33 matured two weeks earlier than the checks, which would give ample time to the farmer to prepare for the next crop and therefore be in time for the new rain season. The varieties also exhibited tolerance to maize lethal necrosis, resistance to turcicum leaf blight, gray leaf spot and common rust which is not surprising since their 
progenitors, namely: AMH704-43, AMH703-35, CKDHL120664 and CKDHL120671 are tolerant to these foliar diseases. It is such characteristics and the excellent morphological traits that make these two hybrids superior to the best check H614D and the other 120 hybrids evaluated at AYT stage. In particular, both hybrids BH31 and BH33 were tolerant to root and stem lodging mainly because of their slightly short stature in comparison to most highland maize varieties on the market. According to Hu et al (2017), if the target is grain yield, breeders prefer a short stature plant as high yielding maize varieties need to be lodging-tolerant under high nitrogen levels and high density planting conditions. It is even evident from the data that taller varieties (e.g. PAN691, H614 and H624) highly root lodged (33 - 35\%) compared to hybrids BH31 and BH33, with only 7 to $17 \%$ root lodging. It is noteworthy that the trait of lodging is associated with grain yield loss (Mi et al., 2017).

Unpredictable environmental conditions are a major constraint to selecting superior and widely adapted maize hybrids. Similar to findings by Kayaga et al (2017), three mega environments for highland maize namely Buginyanya, Kalengyere and the transitional areas of
Bukwo, Bulegeni and Zeu were identified in this study. These were environments that fell in one sector of the polygon (Abdu et al, 2013). Hybrid BH33 won in all environments and can, therefore be regarded as the most stable hybrid across environments. The commercial checks H614D and H624 won only in the eastern Uganda mega environment. Hybrids BH27, BH31 and BH38 won in the transitional altitudes of eastern and northwestern Uganda, namely Bukwo, Bulegeni and Zeu. When evaluated under transitional altitudes in Rwebitaba (Fort Portal District), BH31 and BH33 had much higher grain yield than the commercial checks Bazooka and H624, and with much better, husk cover and fewest ear rots compared to BH27. This confirms that the hybrids BH31 and BH33 perform well both under highland and transitional altitudes.

\section{CONCLUSION AND RECOMMENDATIONS}

The candidate varieties (BH31 and BH33) are characterized by i) medium to late maturity ii) many rows of grain iii) tolerance to MLN and resistance to other key diseases like turcicum leaf blight, gray leaf spot and common rust, iv) lodging tolerance and v) farmer preferred culinary grain qualities (Table 6).

Table 6. Summary of key characteristics of the released hybrid varieties.

\begin{tabular}{llll}
\hline Characteristics & BH31 (NAROMAIZE 731) & BH33 (NAROMAIZE 733) & H614D (Check) \\
\hline Sheath colour & present & present & present \\
Silk colour & Present & Present & Present \\
Taste on roasting & Very sweet & Sweet & Sweet \\
Intensity of green colour & Medium & Medium & Medium \\
Days to maturity & 144 days (Medium to late) & 154 days (late) & 164 days (very late) \\
Time of anthesis & Medium to late & late & late \\
Time of silk emergence & Medium to late & late & late \\
Ear length & medium & long & long \\
Ear diameter & large & Medium & Medium \\
Ear shape & Cylindrical & Conical cylindrical & Conical cylindrical \\
No of rows of grain & Very many & many & many \\
Texture/type of grain & Flint-like & Flint-like & Flint-like \\
Colour of grain & White & White & White \\
Plant height & medium & medium & Tall \\
Ear position & medium & medium & medium \\
\hline
\end{tabular}

Therefore, these varieties are appropriate for cultivation in major highland and transitional maize growing regions in Uganda. These varieties will complement the Kenyan varieties like H614D, H624 and H628 which for long have been the only varieties for highland areas in Uganda even though they are bred in Kenya. Because of their good 
attributes, the two varieties, $\mathrm{BH} 31$ and $\mathrm{BH} 33$, were released on $24^{\text {th }}$ November 2017 by the National Variety Release Committee of Uganda and registered in the national catalogue as NAROMAIZE 731 AND NAROMAIZE 733, respectively.

\section{ACKNOWLEDGMENT}

Special thanks to Dr. Mosisa Regasa (CIMMYT-Kenya), Dr. Dagne Wegary and Dr. Demewoz N. Woreti (CIMMYT Ethiopia) for availing the germplasm. Financial support to undertake these evaluations and selections were largely sourced from the Alliance for a Green Revolution in Africa (AGRA). Staff of NARO (Buginyanya ZARDI, NaCRRI and Kachwekano ZARDI), and Hellen Kayaga from College of Agriculture, Makerere University were instrumental in executing the trials. Many thanks to the extension agents and farmers who took part in the participatory variety evaluation and selection.

\section{REFERENCES}

Abalo, G. 2007. A comparative analysis of conventional and marker assisted selection methods in screening for resistance to maize streak virus disease. PhD Thesis. University of KwaZulu-Natal, Pietermaritzburg.

Abdu, G.,R. Akromah, M.S. Abdulai, K. Obong-Antwi, A.W. Kena, K. Tengan andH. Alidu. 2013. Assessment of Genotype by Environment interactions and Grain Yield Performance of Extra-Early Maize (Zea mays L) Hybrids. J Biol Heal Care.

DSOER.2004. Kapchorwa District State of the Environment Report 2004. Kapchorwa District. Production and Environment Planning Committee. www.nemaug.org/district_reports.

Fews Net.2005. Summary of livelihood zones of Uganda, www.foodnet.cgiar.org.

Gautam, A.S., R.K. Mittaland J.C. Bhandari. 1999.
Correlations and path coefficient analysis in maize (Zea mays L.). Ann. Agri. Bio. Res. 4:169-71.

Hu,S., C. Wang, D.L.Sanchez, A.E. Lipka,E. Liu, Y. Yin, M. Blanco andT. Lübberstedt.2017. Gibberellins Promote Brassinosteroids Action and Both Increase Heterosis for Plant Height in Maize (Zea mays L.). Front Plant Sci. 2017. 8: 1039.

Kayaga, H.N, F. Kagoda, M. Ochwo-Ssemakula, G. Asea, R. Edema, P. Gibson andE.M.B. Alladassi.2017a. Genotype by environment interaction effect on grain yield of highland maize (Zea mays L.) hybrids. Maydica Electronic Publication, Maydica, 62.

Kayaga H.N, F. Kagoda, M.Ochwo-Ssemakula, E.M.B. Alladassi, G. Asea,P. Gibson andR. Edema. 2017b. Inheritance of yield and yield related traits in highland maize hybrids of Uganda. J. Crop Sci. and Biotech. 20 (4) : 255 - 262.

MAAIF.1995. Basic facts on agricultural activities in Uganda.

Magorokosho, C., B. Vivek, M. Bänziger andJ. MacRobert. 2007. Characterization of maize germplasm grown in eastern and southern Africa: Results of the 2006 regional trials coordinated by CIMMYT. CIMMYT, Harare, Zimbabwe.

Mi, C., X. Zhang, S, Li, J. Yang, D. Zhuand Y. Yang.2010. Assessment of environment lodging stress for maize using fuzzy synthetic evaluation. Math.Comput. Model.54 (3-4): 1053-1060.

Oteguia, M.E.and R. Bonhommeb. 1998. Grain yield components in maize: I. Ear growth and kernel set. Field Crops Res. 56 (3): 247-256.

Yan, W. andN.A. Tinker.2006. Biplot analysis of multienvironment trial data: Principles and applications. Can.J. Plant Sci. 623-645.

Publisher's note: EScience Press remains neutral with regard to jurisdictional claims in published maps and institutional affiliations.

Open Access This article is licensed under a Creative Commons Attribution 4.0 International License, which permits use, sharing, adaptation, distribution and reproduction in any medium or format, as long as you give appropriate credit to the original author(s) and the source, provide a link to the Creative Commons license and indicate if changes were made. The images or other third-party material in this article are included in the article's Creative Commons license, unless indicated otherwise in a credit line to the material. If material is not included in the article's Creative Commons license and your intended use is not permitted by statutory regulation or exceeds the permitted use, you will need to obtain permission directly from the copyright holder. To view a copy of this license, visit http://creativecommons.org/licenses/by/4.0/.

(C) The Author(s) 2019. 